\section{Millainen maailma meiltä jää?}

Pihkala, Panu (2017). Päin helvettiä? Ympäristöahdistus ja toivo. Helsinki: Kirjapaja. 301 sivua.

LASTENLASTEMME ASEMAAN asettuminen havahduttaa. Olemmeko ylpeitä niistä olosuhteista, jotka heille jäävät? Vastauksen varmuus kalvaa mieltä. Ilmeistä on se, että elämän jatkuminen on uhattuna ihmisen itsensä eli minunkin vuoksi. Elämme tämän vuoksi ihmiskunnan historian kummallisinta aikaa.

Päin helvettiä? -teoksen ajankohtaisuus liittyy elämäntapojen ja hyvinvointi-ihanteen muutosten välttämättömyyteen. Tiedämme suunnanmuutoksen välttämättömäksi, mutta reagoimme siihen kansalaisina ja yhteiskuntana vain pinnallisesti.

Ehkä kiireinen arki sokeuttaa pitämällä meidät erossa suurista kysymyksistä. Hoidamme ihmiskunnan eloonjäämisen kokoista sairautta keskittymällä oireisiin. Vaihdamme vain lamppuja, vaikka itse sairaus johtuu siitä, että olemme tottuneet tuottamaan energiamme polttamalla kaikenlaista.

Lisäämme hallinnan ja turvallisuuden tuntua pelkistetyillä todellisuuden tulkinnoilla. Ajattelustamme on tullut atomistisempaa, pilkotumpaa ja yhä heikommin kokonaisuuksiin keskittyvää. Todellisuuskäsityksemme ei enää vastaa sitä todellisuutta, jonka osa olemme. Vieraantunut olo syntyy siitä, että intuitiivisesti tiedostam- me tämän kaiken. Se ei tee hyvää mielellemme.

Päin helvettiä? -kirja on kirjoitettu ympäristöahdistuksen ja toivon väliseen jännitteeseen. Ahdistuksen syiden ymmärtäminen on vahva peruste sille, miksi niistä pitää puhua. Mutta samalla täytyy ponnistaa toivon varassa kohti ratkaisuja. Siihen Pihkala kannustaa. Ilman toivoa hyvästä huomisesta ei jäljelle jää juuri mitään.

\section{SUUNNAN VAIHTAMISEN VAIKEUS}

Ihmisen yhteys ilmastonmuutokseen on tiedeyhteisössä selviö. Yhtä selvää on, että talous kasvaa luonnonvaroja jalostamalla. Jotta luonnonvaroista jalostettuja tuotteita menisi kaupaksi, tarvitaan kuluttajia.

Yhä useampi kansalainen on kuitenkin havahtunut siihen, että kuluttamisen lisäämiseen perustuvan hyvinvointi-ihanteen tarkistaminen on välttämättömyys. Ihmiskunnan käytössä on yhden planeetan verran luonnonvaroja ja päästöjen sitomiskapasiteettia - ei sen enempää. Ellemme vaihda suuntaa, päädymme varmuudella juuri sinne, minne olemme kulkemassa.

Pihkala antaa konkreettiset kasvot edistysajattelun tarkistamisen vaikeudelle ottamalla luki-

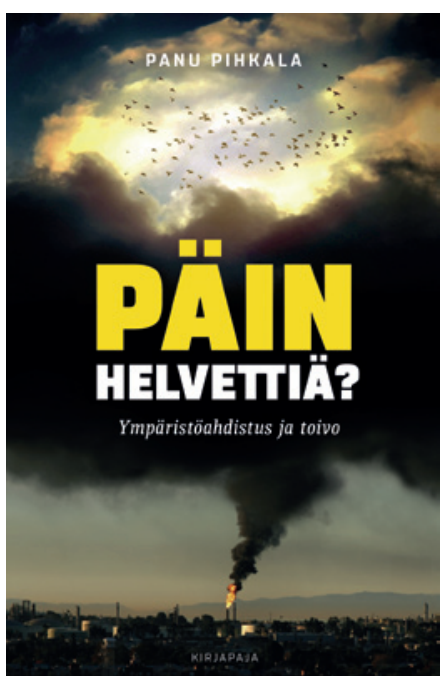

jan laivamatkalle. Matkustajalaiva vertautuu kirjassa törmäyskurssilla olevaan maapalloon ja sen kansalaisiin.

Hankalaksi tilanteen tekee se, että juuri kukaan ei kiistä tarvetta tarkistaa maapallolaivan kurssia. Siitä huolimatta suuntaa ei vaihdeta. Törmäys on vääjämätön. Sen ajankohtaa ei vain tiedetä. Tämän tiedostaminen vie elämänvoimaa ja ahdistaa.

Ympäristöahdistuksen syy on siinä, että tiedämme, mitä pitäisi tehdä, mutta emme tee. Ahdistusta voimistaa puhumattomuuden kulttuuri, joka verhoaa etenkin kielteisiä tulevaisuuteen liittyviä näkymiä.

Suunnan vaihtaminen on helpommin sanottu kuin tehty. Demokraattisessa yhteiskunnassa kansalaisilla on toisistaan poikkeavia todellisuuskäsityksiä. Maapallolaivan kapteenikaan ei kyseenalaista laivan kulkusuuntaa vaan ulkoistaa vastuun: "Mutta laivayhtiö on päättänyt reitin ja minä 


\section{HOIDAMME IHMISKUNNAN ELOONJÄÄMISEN}

KOKOISTA SAIRAUTTA KESKITTYMÄLLÄ

\section{VAIN OIREISIIN.}

olen allekirjoittanut sopimuksen."

Teoksen voima on puhuttelevassa narratiivissa, jolla Pihkala tuo tarkasteltavat asiat lähelle lukijaa. Psykologinen näkökulma ilmastonmuutoksen oloissa elettyyn elämään on ollut aivan liian niukkaa Suomessa. Päin helvettiä? paikkaa tuota puutetta.

\section{MONINÄKÖKULMAISUUS RATKAISUNA}

Pihkalan lähestymistapa on sekä psykologinen että ratkaisuihin tähtäävä. Hän riippuu kiinni toivossa, vaikka tekeekin selväksi, miksi koemme epätoivoa. Teoksen kantava ajatus on, kuinka kehittyä kahden tason näkökyvyssä: kuinka oppia näkemään uhat ja mahdollisuudet yhtä aikaa?

Ympäristöahdistuksen yksi keskeinen syy on se, että kansalaiset kokevat toimivansa arvojensa vastaisesti. Tuskin kukaan suomalainen haluaa kiihdyttää ilmastonmuutosta tietoisesti omilla arkisilla valinnoillaan. Päinvastoin.

Mutta ilmastonmuutoksen kaltaiset viheliäiset ongelmat ovat niin monitahoisia, että ratkaisuja haettaessa tuntuu siltä kuin pitäisi yhtä aikaa soutaa ja huopaa. Poliitikkoja kuunnellessa viestiksi muodostuu tyypillisesti se, että pitäisi sekä lisätä että vähentää kulutusta. Talouskasvu edellyttää kulutuksen lisäämistä, mutta tulevien sukupolvien asemaan asettuminen johtaa päinvastaiseen päätelmään. Moraalinen ymmärryksemme viestii yksiselitteisesti, että on ryhdikkäämpää säilyttää elämisen edellytyksiä kuin tuhota niitä.

Suunnan muuttaminen on monimutkainen prosessi, joka vaatii yhteisen päämäärän tunnistamista ja siihen pääsemistä edistäviä jokapäiväisiä tekoja. Siinä on sijaa ihmisen todellisuuskäsityksen tarkistamiselle mutta myös puhtaille teknologioille, kestävyyskysymysten valtavirtaistamiselle, kansalaisyhteiskunnan voimistamiselle ja kansalaisyhteiskunnan resilienssin vahvistamiselle.

Yksi asia on kuitenkin ylitse muiden: ilman toivoa hyvästä huomisesta elämän voima tukahtuu.

ARTO O. SALONEN

$\mathrm{KT}$, apulaisprofessori

Itä-Suomen yliopisto

dosentti

Helsingin yliopisto 